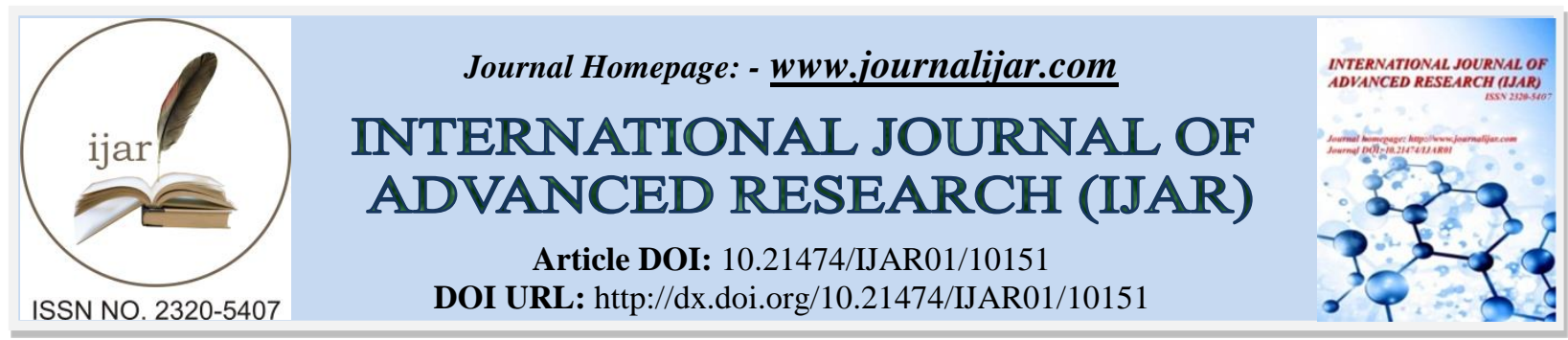

RESEARCH ARTICLE

\title{
EVALUATION IMPLEMENTATION STRATEGIC PLANNING OF HEIS IN THE BALANCED SCORECARD'S CUSTOMER PERSPECTIVE, SETTING IN UNIVERSITAS INDONESIA.
}

Tumbur Tobing ${ }^{1}$, Rugaiyah ${ }^{2}$ and Ivan Hanafi ${ }^{2}$.

1. Student of Postgraduate in Education Management Universitas Negeri Jakarta Indonesia.

2. Professor of Postgraduate in Education Management Universitas Negeri Jakarta Indonesia.

\section{Manuscript Info}

Manuscript History

Received: 03 October 2019

Final Accepted: 05 November 2019

Published: December 2019

\section{Key words:-}

Higher education, Balanced Scorecard, Strategic Planning, Strategic Management, Customer, Key Performance Indicator.

\section{Abstract}

The purpose of this paper is to describe that HEIs require measurable indicators that can reflect one value and excellence that can be achieved through investments in technology, innovation, students, lecturers and staff. Then Higher Education Institutions must have a BSC framework because it can foster connections and build harmony between key performance indicators. The Balance Scorecard (BSC) framework is a superior strategy based on a management system that can be used at HEIs to help how to explain vision and mission and then translate vision into strategy. Through our analysis we show how customers represent as a key importance in the HEIs perception competition. HEIs needs to develop "agile" which means universities must anticipate and respond to changing speeds with high levels of productivity in internal and external relations. So leadership agility is needed, which means that leaders must be sensitive and responsive to changes very quickly. Strategy management in the HEIs region has experienced significant changes from various factors, it is necessary to form more dynamic patterns. HEIs are increasingly focused on performance management results. This development can be seen from the growing competition between HEIs.

Copy Right, IJAR, 2019,. All rights reserved.

\section{Introduction:-}

\section{Profile University of Indonesia:}

The vision of the University of Indonesia for the period of 2015-2019 is "Realizing Public University to be an independent and superior State Legal Entity that is able to solve problems and challenges at the national and global level, towards excellence in Southeast Asia. The mission is: 1) broad and fair access, quality education and teaching; 2) quality Tridharma * activities that are relevant to national and global challenges; 3 ) creating graduates with high quality, virtuous character, and able to compete globally; 4) creating an academic climate that is able to support the realization of the University of Indonesia's vision. The general policy of the University of Indonesia as an integrated entity with a strong foundation in the form of: 1) ethical and moral academic excellence, 2) the quality of human resources oriented to the performance, integrity and integration of the academic community, 3) transparent university governance principles, accountable, responsible, independent, and fair, 4) fundraising from the public sector and industry towards the establishment of the university's endowment fund to achieve long-term goals, 5) leadership that establishes truth, honesty and justice with a spirit of collegiality, 6) optimizing resources resourcebased use of shared costs and resources (cost sharing and resource-sharing). The objectives of the University of 
Indonesia: 1) create an inclusive education community; 2) students become smart and conscientious graduates; 3) develop and disseminate science, technology, and culture; 4) encourage and strengthen the development of existing sciences, new sciences and studies, 5) encourage and support the active participation of the academic community in development and community service; 6) role as the organizer of higher education, and in collaboration with institutions and professional associations; 7) improve the quality and quantity of services to the nation, country and the world through collaboration, partnerships, and opportunities for cultural enrichment and continuing education; 8) invest in professional development for all citizens of the University of Indonesia and useful technology in order to achieve competitive advantage through teaching, research, and community service Figure \& Fact about the University of Indonesia.

Strategic performance and measurement are very important for Higher Education Institutions. To evaluate performance from the customer perspective, must consider external customers such as the perspective of business employers, parents who pay tuition, students. Refer to (O’Neill, 2003) Students are the main customers for university ability to meet or exceed student demands contributes to student retention and increases their propensity to recommend their school to others. Furthermore, (Dubrovski, 2001) explain that student (customer) retention and referrals have been shown to be important for organizational success and business development. Researchers cite research findings from (Kotler, P., \& Fox, 1995) suggesting that students must be satisfied with the academic aspects of the service provided by their universities (the product).

This study aims to evaluate the implementation of a strategic plan with an approach from the perspective of the Balanced Scorecard, with sub focus namely: Customer (Stakeholder): 1.1 Internal: Excellent university reputation.1.2 External: a) Excellent and competitive graduates, b) Excellent research and international reputation, c) Contribution to the development of the people of Indonesia and the world.

Building a true and healthy organization has a focus on performance. Performance is needed through how to measure and how to achieve targets that are challenging. Key performance indicators (KPI) become performance measurement tools because what cannot be measured can never be managed and resolved properly.

The effectiveness of an organization or called the performance of an organization to show the extent to which the organization has achieved its goals. Work performance or results or work performance. Jack Welch stressed that, "establish performance as a key company priority" (Krames, 2005)

Then the researcher argues the importance of BSC relating to the performance process in the management of organizations that have the aim to improve on improvements that are efficient, as researchers cite the abstraction from (Vukšić, Bach, \& Tomičić-Pupek, 2014): Process management has become one of the most important management tools in profit organizations. However, non-profit organizations also started to benefit from Process Performance Management aimed at the efficiency improvement. Performance can be divided into two categories. First, performance in the context of making changes is to reflect efforts to bring the organization to a higher level of performance. Second, performance is related to business as usual (maintaining health) operations aimed at maintaining a good level of performance and has been standardized can be maintained at that level. On the other hand, the Balanced Scorecard helps the organization to balance what needs to be raised as a priority at the strategic level and what is sufficiently placed on the operational order (work unit).

The balanced scorecard is a tool for measuring management performance (performance management tools) by utilizing a set of financial and non-financial indicators that are all intertwined in a causal relationship.

Balanced scorecard is a management of organizational performance, balanced and aligned to be achieved. The word "balanced" means balanced about the achievement of current and future performance. Aligning to reflect performance at the work unit level must encourage the achievement of strategic priorities at the organizational level. (Robert S. Kaplan dan David P. Norton, 1996) (Kaplan, Robert S. dan Norton, 2006) further state that: The balance scorecard enabled the early-adopting companies to focus and align their executive teams, business units, human resources, information technology, and financial resources to their organization's strategy. Previously (Robert S. Kaplan dan David P. Norton, 1996) suggested that using a balanced scorecard made the organization adopt the level of alignment and focus of the executive team of business units, human resources, information technology, and finance with organizational strategies. The balanced scorecard has four advantages if implemented correctly: a) Clarify and translate vision and strategy, b) Communicate and link strategic objectives and measures, c) Plan, set 
targets, and align strategic initiatives, d) Enhance strategic feedback and learning. (Robert S. Kaplan dan David P. Norton, 1996)

More clearly (Robert S. Kaplan dan David P. Norton, 1996) explain the description of each of their perspectives on The Customer Perspective that, current management philosophy has given a growing awareness of the importance of customer focus and customer satisfaction in every business venture. This is a key indicator: if a customer is dissatisfied, resulting in the customer eventually finding another supplier who can meet customer needs. Poor performance from this perspective will show a declining indicator in the future, even though the business financial statements show good conditions.

\section{HEIs Perspective Development:}

(Singh, 2016) suggested that the purpose of higher education is to prepare intellectual regeneration, as a generation and have an enlightenment spirit in society, "the higher education is that which does not merely give us information, but makes life in harmony with all existence". Higher education is of vital importance for the country, as it is a powerful tool for building knowledge-based society of the 21 st century. Higher education can play an instrumental role in the achievement of these outcomes through the creation of knowledge networks, research and innovation centers, corporate-backed institutions, and support for faculty development. Researchers interpret that, Society as a whole must support education at all levels, including higher education, given its role in promoting sustainable economic, social and cultural development "

Changes in the global world make the world of higher education experience a dynamic shift in meaning and technological revolution associated with one another. Researchers cite the thoughts of (Castagna, Colantonio, Furia, \& Mattoscio, 2010) regarding the reality of the dynamics of global development: First, In modern globalized economies, stratified knowledge comes to be a key productive asset, and the role played by education in the economic process is decisive. Second, the capacity to innovate of a country is linked to human capital. Human capital is a crucial component of growth dynamics in both industrialized and developing countries. Third, the relationship between education and growth, which finds that the countries ability to innovate or catch up more advanced countries seems to be affected by the stock of human capital which is consider a driver of growth. Human capital accumulation is a source of sustained growth in alternative to technological change. Fourth, Investments on education and research are not effective if they cannot meet the training needs of the labor market.

(Ron Germaine, Jan Richards, Marilyn Koeller, 2016) say that the 21st century causes changes and adjustments must be fast in the development of technology and the rapid availability of information due to the demands of the globalization era. Higher education must follow 21st Century Skills covering four main focus (4Cs): 1). Critical thinking and problem solving skills 2). Communication skills, 3). Collaboration skills, 4). Creativity and innovation skills. The reality of the global market allows higher education reform because of the digital influence that is very fast and has an up to date significance value. Then the researcher broadens the insight of thought by citing Cornali and Tirocchi's (2012) thoughts on the characteristics of global education; First, Decentralization. Second, Assessment, pursuing a better quality of education. Third, Privatization is seen as that which has the greatest impact in the field of education. In other words, Globalization and the digital revolution have had a major impact on teachers' and learner's identities, because the global landscape implies a change in subjective and inter-subjective sociality and the new relationships between individuals and institutions. However, (Kivunja, 2015) quoted Tapscott's warning, "students won't be prepared for the world of today unless school uses technology to implement real change to their model of education". That real change can be facilitated by the introduction of social media technologies which are noted above, are the preferred media platforms for collaboration, information sharing and critical thinking among the learners of the 21 st century classroom.

(Lichy \& Enströ, 2015) added, HEIs requires a great effort to improve student learning and must be relevant in the 21 st century requiring business innovation models. Digital technology has changed the way business works into new patterns that are used by users free of charge. HEIs must be ready to compete in a business model that is getting shorter in age, so HEIs leaders need a measurement tool, expertise and experience to anticipate it, test equipment and implement a new business model to gain innovation momentum. HEIs that succeed in the future will utilize the intellectual capacity of educators and increase the intellectual capital of each educator by making network partners. Advances in information technology will accelerate network development beyond the boundaries of scientific disciplines. Research responses from (Machado \& Taylor, 2010) present fact finding HEIs development; First, HEIs needs to interpret the vital needs of contemporary society, 'to live in the market', to be 'innovative' as well as to 
develop internal structures to fulfill their new mission. HEIs are an important symbol of national identity and a repository of people's history, language and culture. Second, 21st century challenges for HEIs include demographic change, reduction in per capita funds, increased oversight from the public. Other challenges include a global knowledge economy; society driven by technology; turbulent environment. Third, as HEIs increase their penetration in the market, academics will increasingly be seen as 'intellectual workers'. Fourth, HEIs are a central element in the knowledge society, setting goals to become the most competitive and dynamic knowledge-based economy in the world for sustainable economic growth. Fifth, demands on HEIs place great responsibility on governance and management at the institutional level, the need to use strategic management the steering of HEIs at this time. Sixth, strategic planning is a specific method, strategies are formulated and implemented taking into account the context of the organization's environment, enabling institutions to obtain sufficient resources to achieve their objectives. Seventh, strategic planning must be considered for HEIs; a). improve performance towards achieving mission statements; b). improve performance towards improving the academic position of the institution; c). improve achievements with the same or lower level resources; d). clarifying the future direction of the institution; e). meet the accreditation requirements or government institutions; f). solving major problems (threats) or overcoming significant opportunities facing the institution. g). provide opportunities for leadership like when appointing a new president. h). uniting the HEIs community in collaborative efforts

\section{Implementation of the Balanced Scorecard Approach:}

Researcher wants to elaborate the significance of BSC as follows; refer to (Hutabarat Jemsly, Huseini, 2012) that have been tested in various companies and non-profit institutions because they have advantages and are very significant because they have the benefits of: a) as a more comprehensive strategic tool, b) as a strategic process because it clarifies and communicates strategy to the entire organization, c) dealing directly with finance, because every target is related to finance, d) helping to apply a transparent management culture, e) changing the way companies work to be more efficient and effective through a measurable and informative system, f) management can focus resources on performance measures, g) as an organizational learning process through a repeat of the strategic cycle, h) improve the communication strategy platform in the organization that reflects the relationship between top management and employees, i) performance drivers, j) executive commitment, because executives have a scorecard.

(Rothaermel, 2015) further refined the idea of the BSC, saying that, "Balanced scorecard can accommodate both short-and long-term performance metrics. It provides a concise report that tracks a chosen metrics and measures and compares them to target values. " The balanced scorecard allows managers to trace past performance, then identify areas for improvement, then place the organization for the next phase to achieve growth. The balanced scorecard becomes a broad analytical tool and is equipped with financial calculations in operations measuring customer satisfaction, internal processes, and innovations and improvements in the organization. Researchers cite conclusions from (Mulyadi, 2014) that the Balanced Scorecard 1) is not just a system of measuring the performance of leaders; 2) not just a translator tool for vision, mission, goals, basic beliefs, basic values, and strategies, 3) and not panacea, which is a panacea to overcome all kinds of diseases. In other words, the Balanced Scorecard is a change in management style towards organizations, both profit-motivated organizations and nonprofit organizations.

As it is known that BSC in nonprofit organizations, especially higher education has a different schema chart with profit organization, (Khatoon \& Farooq, 2014) emphasized that BSC perspective on HEIs, "Replacing customers with students and academic interpretation of the other three perspectives organize the BSC for universities. Studies reveal that BSC colleges use developing frameworks for measuring institutional effectiveness on the macro level. BSC provides a university administration with a measurement system that is not only linked to mission and strategy, but also a learning model that maintains continuous improvement and environmental responsiveness. The BSC is both a performance measurement and management tool that enables the organization to clarify their vision and strategy and translate them into achievements. "

HEIs are increasingly focused on performance management results. This development can be seen from the growing competition between HEIs. (Papenhausen, 2006) explains that in the Balanced scorecard model there is a Strategy map which shows the organizational strategy on one page so that it can be understood as a whole about the effectiveness of the organizational strategy: "The strategy map is a visual representation of an organization's strategy that describes the logic of the strategy by representing the objectives for the critical internal processes that create value and the organizational learning and growth that support those processes. The Balanced Scorecard strategy map will develop three influential parts and complementary strategic themes: 1) Teaching themes - selection and retention of faculty who are focused on teaching excellence to gain an increased market share of the educational 
market. 2) Research themes-identification of college faculty as dedicated research colleagues desiring to be champions in their chosen fields. 3) Outreach themes-use college faculty to support regional education and other intellectual support.

Stakeholder (Customer) Perspective Evaluation Results in University of Indonesia. Through the figure and table below, the researcher will explain the findings as follows:

\section{Excellent University Reputation:}

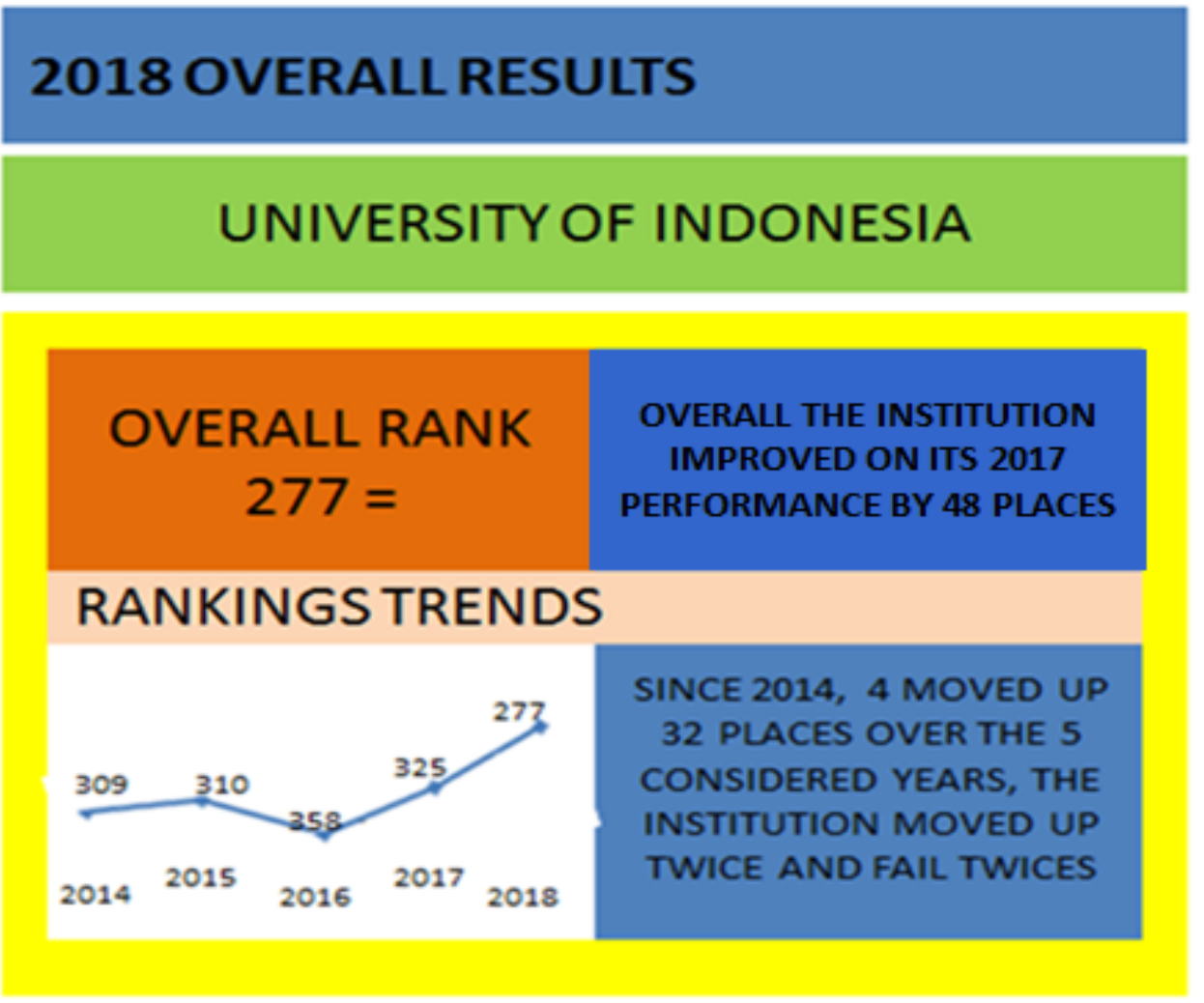

Figure 1:- UI ranking in QS WUR (World University Ranking) 2018.

Through this strategic goal UI has succeeded in achieving 277 ranking in the QS Top University Ranking. Referring to the target set, the realization of the achievement exceeded the target of 310 . This result also shows an increase in rank compared to 2016, which is 325 . The increase in UI ranking is supported by the number of study programs that have been accredited at the national and international levels from the target of 21 study programs that received accreditation at the level Internationally there have been as many as 23 study programs. AUN accredited study programs were 20 study programs and 1 study program had been re-accredited, 3 other study programs were accredited by international accreditation institutions namely APACH, ABEST, and IABEE. For the national level the number of study programs accredited A at the National Level / BAN-PT of the target 170 study programs has been realized to be 175 study programs with a value of $\mathrm{A}$.

\section{Excellent and competitive graduates:}

To find out the quality of UI graduates, a tracer study is conducted annually. Tracer study is carried out using a questionnaire and the focus of the questions is related to the graduates themselves and the satisfaction of users of UI graduates. In 2017 the process obtained from tracer study is a value that compares the quality of UI graduates with the quality of non-UI graduates from foreign universities. The value obtained is 4.7 from 5 Likert scale. As for the tracer study, the quality of graduates obtained a value of 4.8 on a Likert scale.

\section{Excellence research and international reputation:}

In the period during 2017 the number of intellectual property and awards obtained by 356 IPRs and awards for the number of IPRs exceeded the set target of 324 IPRs and awards. 


\section{Contribution to the development of Indonesian society and the world:}

Until the end of the 2017 period, 260 community service activities have been carried out from the 258 set targets. The stakeholder perspective and customer perspective on the UI balanced scorecard are a unity. According to researchers, this refers to the strategic commitment, "Excellent University Reputation", is the key to national and international recognition through the accreditation and quality of graduates as contributing to the progress of the nation and the "career path" in the public sphere. Researchers quote thoughts from the journal (Hart, Rampersad, Lopez, \& Petroski, 2009) Alison Jose, and Michael who say that, "that service quality and customer satisfaction are essential to organizations' profits and overall business success. For institutions of higher education, most of which are non-profits, are not publicly traded, and, therefore, lack of common market-driven performance measures, evaluation of customer (student) satisfaction can be an effective method of incorporating important stakeholders' opinions into the performance measurement process. "

This becomes an in-depth study in the era of global competition that must be faced by every HEIs, then Hart et al. Further said that service quality is strongly correlated with customer (students') satisfaction. Research demonstrates that administrators have to be concerned with how employers, current students and alumni value the skills and competencies taught as well as the overall education experience. When looking at higher education, researchers have confirmed a positive relationship between student satisfaction with academics and overall student (customer) satisfaction. Studies have found that most students are satisfied with the academic aspects of the service provided by their universities (product); However, they are less satisfied with support services, including academic advising, registration, and career counseling. Trust, consistency, and the timely handling of student issues by administrators have also been found to be the key contributors to student satisfaction or dissatisfaction. "

\section{Discussion:-}

On Stakeholders (Customers) Perspective Study: The discussion of the evaluation of the implementation of strategic planning UI period 2015-2017 on the perspective of stakeholders in two parts, namely internal and external.

The author focuses on the existence of UI universities on the value of achieving strategic goals, namely Excellent university reputation, giving optimal results, showing a trend that is getting better and exceeding the target of the Directorate General of Higher Education, which ranks 400th in the world. The QS world ranking includes assessment indicators: Academic reputation, Employer reputation, Student-to-faculty ratio, Citations per faculty, International faculty ratio, and International student ratio.

Table 1:- Perspectives of Stakeholders

\begin{tabular}{|c|c|c|c|c|c|}
\hline \multirow[t]{2}{*}{ Perspective } & \multirow[t]{2}{*}{ University Strategic Targets } & \multirow[t]{2}{*}{ University Indicator } & \multicolumn{3}{|c|}{ Outcomes (Years) } \\
\hline & & & "15 & $' 16$ & 17 \\
\hline \multirow[t]{11}{*}{ Stakeholders } & $\begin{array}{l}\text { Excellent University } \\
\text { Reputation }\end{array}$ & QS World Ranking & 358 & 325 & 277 \\
\hline & & $\begin{array}{l}\text { Number of International accreditation study } \\
\text { programs }\end{array}$ & 17 & 20 & 23 \\
\hline & & Number of national accreditation study programs & 145 & 162 & 175 \\
\hline & $\begin{array}{l}\text { Excellent \& Competitive } \\
\text { Graduates }\end{array}$ & $\begin{array}{l}\text { The quality of graduates of tracer study results on } \\
\text { a scale (1-6) }\end{array}$ & NA & NA & 4.8 \\
\hline & & $\begin{array}{l}\text { Competitiveness is calculated from the } \\
\text { comparison between UI graduates and Non UI PT } \\
\text { Overseas (scale 1-6) }\end{array}$ & NA & NA & 4.7 \\
\hline & $\begin{array}{l}\text { Excellent research and } \\
\text { international reputation }\end{array}$ & Citation per paper & & 0.2 & 0.1 \\
\hline & & Total intellectual property \& rewards $(1-4)$ & & 3.1 & 3.2 \\
\hline & $\begin{array}{l}\text { Contribution to the } \\
\text { development of Indonesian } \\
\text { society and the world }\end{array}$ & $\begin{array}{l}\text { The number of licenses and start-ups that get } \\
\text { investment compared to the total licenses and } \\
\text { start-ups that are eligible (percentage) }\end{array}$ & NA & NA & 23 \\
\hline & & $\begin{array}{l}\text { The amount of community serviceactivities } \\
\text { comes from the UKK, faculties and individual } \\
\text { lecturers }\end{array}$ & & & \\
\hline & & Faculty & NA & NA & 260 \\
\hline & & uा & NA & NA & 260 \\
\hline
\end{tabular}


Then the researchers showed that the increase in national-level Study Program accreditation had exceeded the UIDikti performance contract, namely the number of Excellent (A) accreditation was 158 study programs and UI was able to reach 175 study programs.

Furthermore, for the international study program, the accreditation is very significant. In 2017, UI became the first and only University to be assessed by AUN-QA (ASEAN University Network-Quality Assessment), which scored 5 (Better than Adequate) for all assessment components, namely: Strategic QA, Systemic QA, Functional QA, and Result. These results indicate that the UI has met and exceeded the AUN-QA Framework and Criteria requirements at the institutional level. Performance in the application of QA shows good results, with an increasing trend in UI output trend analysis.

For graduates who are globally competitive, showing a scale of 4.7, 4.8 is increasingly towards perfection (scale 16) this shows that the quality of UI graduates locally or outside has a significant Superior value.

Excellent and internationally reputed research is gaining global recognition on a scale of 3.2 (scale 1-4) with a citation per paper 0.1. increased scientific publications and the acquisition of Intellectual Property Rights (IPR) succeeded in empowering networks of expertise or expertise. Another thing is because it successfully sharpens and solidifies the implementation of research that is focused on superior fields that are unique and multidisciplinary.

\section{Conclusion:-}

Researchers provide conclusions based on the formulation of the problem as follows: Expectations of UI Stakeholder perspective to be achieved, Strategic goal: Excellence University Reputation. Key Performance Indicator (KPI): QS World Ranking UI Ranking and Percentage of user satisfaction levels:

Excellent University Reputation, the researcher concludes that the QS World Ranking Accreditation Ranking Trends has improved from 2015 to 310, dropped in 2016 to 358 then 2017 increased to 325, and in 2018 experienced a very significant increase to 277. The researcher concludes that Excellent University Reputation has very significant achievements because UI's reputation continues to rise from the targeted rankings. The perspective applied to the balanced scorecard at UI is already referring to strategic commitment, excellent university reputation because it is the key to national and international recognition of the accreditation and quality of graduates as a contribution to the advancement of the nation's "career path" in public space.

Graduates who excel and are competitive, researchers conclude that the quality of UI college graduates and the competitiveness of UI graduates with non-UI and foreign universities in the category is sufficient, but have not yet achieved the mission of UI colleges that the quality of UI graduates must be more than the category enough or socalled good. Furthermore, the researcher concludes that high quality human resources are strongly correlated with the competitiveness of graduates who are able to compete at the national and international levels because UI universities have high intellectual assets and highly reputable campus reputation so the benchmark of success of UI colleges is the value selling high in public spaces and career spaces.

Excellent research and international reputation, the amount of intellectual property (Intellectual Property Rights) and the rewards exceeded the target set. Indicator citation of Scopus has not reached optimal results because the document's exposure level is less than one year.

Can the contribution to the development of the people of Indonesia and the world be fulfilled to the maximum? Community service activities have increased significantly and are beneficial to the community such as the activities of UI's own universities or collaboration with institutions outside and within the Ministry of Research, Technology and others.

Evaluation Results Implementation of Strategic planning at UI on the basis of balanced scorecard tools, in general, has shown the achievement of good results. However, in encouraging dynamics to improve the workings of strategic planning that really needs seriousness and renewal through creativity according to the context for the coming period, the researchers provide the following recommendations:

The vision, mission, and objectives of the targets, as well as the strategies to be achieved need to build mutual synergy. The commitment of UI to be an independent and superior PTN-BH in Southeast Asia with evaluation 
criteria is clear and realistic which correlates with the goals of UI so that students have intelligent graduate capacity and have a selling point of professionalism that is of global competitiveness.

Recruiting students and lecturers needs to have intensity with the best quality consistency from all over Indonesia that is not based on mapping of ethnicity, religion, race, between groups. Research culture must be a barometer that has been built since students joined UI and the passion for producing superior research was born from lecturers and professors.

Human is "intellectual capital" which is an asset and is a critical driver to always be sustainable in an organization that is in the competition room and is global rather than local. The university is a printer of future-valued assets with a long-term scope of quality that does not fade and long lasting in every era.

The main focus in the University of Indonesia must be to invest in intellectual capital to have a sustainable reputation in every different era and civilization that changes according to the context of the times.

Human performance in this case intellectual capital is dynamic but has a long-term commitment and is uninterrupted because of sectoral interests or changes in direction of the University of Indonesia, because human is a benchmark of intellectual capital that is produced always has a global quality value.

\section{Recommendation:-}

Teaching and research perspective is a benchmark of success that starts with a long term stakeholder value which refers to two elements namely productivity strategy which includes innovation center and research center is a portrait of the seriousness of the University of Indonesia to develop innovation through the breadth of global quality research. Then the growth strategy that includes a quality research center and center of excellence is an integrative level of international recognition because research quality and superior culture are the highest keys to achieving success within the scope of global reputation.

Student and Partners perspective, is what sustains the success of teaching and research perspective because it has a stakeholder value proposition with six scopes: the agent of change, quality graduates, alumni career path, competitiveness, networking and development. This picture makes students and partners become integrated with each other to tread personality and identity as a scientist, professionalism, entrepreneur who continues to grow and network by having the strength of quality in accordance with the reputation of the UI which is a trendsetter in the public space through education to produce the quality of a student global quality not local, forming students and partners through four categories namely teaching excellence, curriculum excellence, quality of faculty, efficiency \& effectiveness of service. The four categories are the backbone forming the process of maturity of the personality and identity of students and partners into a commitment that is built through sincerity to continuously upgrade and to achieve quality values that are long-term and contextual.

Terms:

UI : Universitas Indonesia (University of Indonesia)

PTN BH: State University as a legal entity

BPMA : The Academic Quality Assurance Agency

HKI $\quad$ : Intellectual Property Rights

Tri Dharma Perguruan Tinggi: (Three Pillars of Higher Education comprising Education, Research and Community Service)

\section{References:-}

1. Castagna, A., Colantonio, E., Furia, D., \& Mattoscio, N. (2010). Does education play a relevant role in globalization? Procedia - Social and Behavioral Sciences, 2(2), 3742-3750. https://doi.org/10.1016/j.sbspro.2010.03.582

2. Dubrovski, D. (2001). The role of customer satisfaction in achieving business excellence. Journal Total Quality Management Volume 12, 2001 - Issue 7-8, 12 issue 7.

3. Hart, L., Rampersad, A., Lopez, J., \& Petroski, M. (2009). Ethnicity and the Balanced Scorecard's Customer Perspective: The Case of Higher Education. The Journal of Applied Business and Economics, 9, 1. Retrieved from

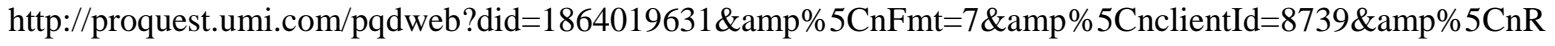


QT=309\&amp\%5CnVName=PQD

4. Hutabarat Jemsly, Huseini, M. (2012). Strategi: Terpadu, Komprehensif, Simultan.

5. Kaplan, Robert S. and Norton, D. P. (2006). Alignment using the Balanced Scorecard to create corporate synergies. Boston: Harvard Business School Publishing.

6. Khatoon, S., \& Farooq, A. (2014). Balanced Scorecard to Measure Organizational Performance: A Case Based Study. The International Journal of Business \& Management, 2(9), 2321-8916. Retrieved from www.theijbm.com

7. Kivunja, C. (2015). Innovative Methodologies for 21st Century Learning, Teaching and Assessment: A Convenience Sampling Investigation into the Use of Social Media Technologies in Higher Education. International Journal of Higher Education, 4(2), 1-26. https://doi.org/10.5430/ijhe.v4n2p1

8. Kotler, P., \& Fox, K. (1995). Strategic Marketing for Educational Institutions. Upper Saddle River, NJ: Prentice-Hall.

9. Krames, J. A. K. (2005). Jack Welch and the 4E's of Leadership (The McGraw). New York.

10. Lichy, J., \& Enströ, R. (2015). Rethinking Business Models for 21st Century Higher Education: A European Perspective. 4(4), 119-127. https://doi.org/10.5430/ijhe.v4n4p119

11. Machado, M. D. L., \& Taylor, J. S. (2010). The struggle for strategic planning in European higher education: the case of Portugal. Research in Higher Education Journal, 6(March), 1-20. Retrieved from http://bibliotecadigital.ipb.pt/handle/10198/2280

12. Mulyadi. (2014). Balanced Scorecard, Sistem Terpadu Pengelolaan Kinerja Personel Berbasis (3rd Edition). Yogyakarta: UPP STM YKPN.

13. O'Neill, M. (2003). The influence of time on student perceptions of service quality: the need for longitudinal measure. Journal of Education Administration, 310-324.

14. Papenhausen, C. and E. W. (2006). Insight from the Balanced Scorecard Implementing the Balanced Scorecard at a College of business, Retrieved from https://doi.org/10.1108/13683040610685757

15. Robert S. Kaplan and David P. Norton. (1996). Translating Strategy into action The Balance Scorecard.

16. Ron Germaine, Jan Richards, Marilyn Koeller, C. S.-I. (2016). Purposeful Use of 21st Century Skills in Higher Education. Journal of Research in Innovative Teaching, 9(1), 19-29.

17. Rothaermel, F. T. (2015). Strategic Management (2nd ed.). New York: Mc-Graw Hill Education.

18. Singh, J. D. (2016). HIGHER EDUCATION IN THE 21ST CENTURY: ISSUES AND CHALLENGES. (December). $\quad$ Retrieved from https://www.researchgate.net/publication/311618391_HIGHER_EDUCATION_IN_THE_21ST_CENTURY_I SSUES_AND_CHALLENGES/download

19. Vukšić, V. B., Bach, M. P., \& Tomičić-Pupek, K. (2014). Process performance management in higher education regular paper. International Journal of Engineering Business Management, 6(1), 1-8. https://doi.org/10.5772/58680. 